ISSN 2519-2523 (print)

Chornomors'ka

mynuvshyna. - 2019. - No.14.

DOI: $10.18524 / 2519-2523.2019 .14 .187096$

УДК 94(477) “16/17”

\title{
TO THE QUESTION ON PECULIARITIES OF UKRAINIAN-TURKISH AND UKRAINIAN-TATAR RELATIONS IN THE LAST THIRD OF XVII - EARLY XVIII c.
}

\author{
Liudmyla Novikova \\ ORCID: https://orcid.org/0000-0003-4764-7867 \\ Ph.D (History), Associate Professor \\ Odesa I. I. Mechnikov National University \\ 2, Dvoryanska Str., Odessa, 65082, Ukraine \\ lyudmilanovikova@hotmail.com
}

The article explores the problem of Ukrainian-Turkish and Ukrainian-Tatar relations in the last third of XVII century - early XVIII century. This period was marked by the regrouping of political interests in Central and Eastern Europe, when the created system of peace treaties and its evolution gave the Ukrainian hetmans various fears about the fate of Ukraine, encouraged them to search for contacts with Crimean Khanate and Ottoman Empire. In these contacts at the state and especially public level, there was already a sufficiently controversial tradition. The ideological context associated with the phenomenon of identity (Cossack, Ukrainian) also played its role, which often entered into contradiction with the ideological frame of the real time policy. At the same time, in turn, the representatives of Crimean Khanate and Ottoman Empire had their own imaginationits toeards and tradition concerning Ukrainians,, which were formed in the context of their attitude to Christians, and also were determined by secular considerations of prey and economic benefits. Due to these reasons, the Ukrainian-Turkish and Ukrainian-Tatar relations of this time were a complex phenomenon, which, despite the existing historiography for example, it should be mentioned the works by O. Galenko, T. Chukhlib), requires additional investigation. In addition to research the factual history if phenomenon and made attempt to reconstruct the Ukrainian-Turkish and Ukrainian-Tatar relations in this period as a certain system, in the article another attempt was made to outline the structure of the problem.

The analysis of Ukrainian-Turkish and Ukrainian-Tatar relations in the last third of XVII century - on the beginning of XVIII c. conducted with using the official and narrative sources, allowed to allocate the following directions, studying of which is needed to reveal various aspects of the problem: terminology, the study of hostile relations in the context of secular and religious ideas, the study of allied and peaceful (included with social assimilation) relations; the study of the main motivation used to substantiate the necessity of unions with Crimean Khanate and Ottoman Empire in the conditions when Orthodoxy acted the role of the center of Ukrainian identity; analysis of the use of the Ukrainian-Tatar and Ukrainian-Turkish relations to form the pantheon of heroes and give positive or negative characteristics to individual figures, depending on the discourse and tasks of authors of texts. It is also important to study the psychological aspects of relations, the influence of mentality, emotions, in the context of the concepts of "offence" and "fear". The study of these areas showed the complexity of the very concept of "Ukrainian-Turkish and Ukrainian-Tatar relations", their different and even opposite directions, dependence on political and ideological factors, their influence on the formation of public discourse. 
Key words: Ukrainian-Turkish relations in the last third of XVII century - on the beginning of XVIII c.; Ukrainian-Tatar relations in the last third of XVII century - on the beginning of XVIII c.; Crimean Khanate; Ukrainian Hetmanate and its society; Ukrainian Cossacks; the history of ideas in Ukraine in the early modern period.

Аюдмила Новікова

ORCID: https://orcid.org/0000-0003-4764-7867

Кандидат історичних наук, доцент Одеського національного університету імені І. І. Мечникова Вум. Дворянська, 2, Одеса, 65082, Україна lyudmilanovikova@hotmail.com

\section{ПРО ОСОБАИВОСТІ УКРАЇНСЬКО-ТУРЕЦЬКИХ ТА УКРАЇНСЬКО-ТАТАРСЬКИХ ВІДНОСИН В ОСТАННІЙ TPETИНI XVII - HA ПОЧATKY XVIII CT.}

У статті розглядаеться проблема украӥнсько-турещьких та украӥнськотатарських відносин в останню третину XVII cm. - на початку XVIII cm. Цей період був позначений перегрупуванням політичних інтересів в ЦентральноСхідній Європі, коли створювана система мирних договорів та ї̈ еволюиія породжувала в українських гетьманів різні побоювання щодо долі Украӥни, спонукала їх до пошуку контактів з Кримським ханством та Османською імперією. У иих контактів на державному та особливо суспільному рівні існувала вже достатньо супереилива традииія. Свою роль відігравав й ідейний контекст, пов'язаний з феноменом ідентичності (козащької, украӥнської), що часто вступав у протиріччя з ідеологічним обрамленням реальною політики часу. Водночас своє уявлення та традииію щодо української сторони мали, в свою чергу, представники Кримського ханства та Османської імперії, що формувалися в контексті їх ставлення до християн, а також визначалися світськими міркуваннями здобичі та економічної вигоди. Внаслідок вказаних причин українсько-турецькі та українсько-татарські відносини цъого часу були складним явищем, яке, незважаючи на існуючу історіографрію (наприклад, праиі О. Галенка, Т. Чухліба), потребуе додаткового дослідження. Крім вивчення фактичного матеріалу та спроби реконструкиії українськотурецьких та украӥнсько-татарських відносин в обраний період як певної системи, у статті була здійснена спробу окреслити можливу структуру проблеми.

Проведений із залученням офіиійних та наративних джерел аналіз українсько-турецьких та українсько-татарських відносин в останню третину XVII cm. - на початку XVIII $\mathrm{cm}$. дозволив виділити наступні напрямки, вивчення яких дозволяе розкрити різні аспекти проблеми: термінологічний, вивчення ворожих відносин у контексті світських та релігійних ідей, дослідження союзних та мирних (включно з соиіальною асиміляцією) відносин; вивчення головної мотивації, що використовувалася для обтрунтування необхідності союзів з Кримським ханством та Османською імперією в умовах, коли православ'я виступало осередком украӥнської ідентичності, аналіз використання українсько-татарських та украӥнськотурещьких відносин для формування пантеону героїв та надання позитивних чи негативних характеристик окремим діячам, в залежності від дискурсу та завдань авторів текстів. Також важливим $е$ напрямок дослідження психологічних аспектів відносин, впливу ментальності, емоцій, у контексті 
понять "кривди" та "страхів". Дослідження иих напрямків виявило складність самого поняття "українсько-туреиькі та українсько-татарські відносини", їх різновекторність, залежність від політичних та ідеологічних чинників, вплив на формування суспільних дискурсів.

Ключові слова: українсъко-туреиькі відносини в останній третині XVII - на початку XVIII cm.; українсько-татарські відносини в останній третині XVII - на початку XVIII cm.; Кримсъке ханство; украйнський Гетьманат та його суспільство; украӥнське козаитво; історія ідей в Украӥні в ранньомодерну добу.

Остання третина XVII ст. - початок XVIII ст. були позначені перегрупуванням політичних інтересів в Центрально-Східній Свропі. Створювана система мирних договорів та іiі евоцюція породжувала в українських гетьманів різні побоювання щодо долі України, спонукала їх до пошуку контактів з Кримським ханством та Османською імперією. У цих контактів на державному та особливо суспільному рівні існувала вже достатньо суперечлива традиція. Свою роль відігравав й ідейний контекст, пов'язаний з феноменом ідентичності (козацької, української), що часто вступав у протиріччя з ідеологічним обрамленням реальної політики часу. Водночас своє уявлення та традицію щодо української сторони мали, в свою чергу, представники Кримського ханства та Османської імперії, що формувалися в контексті їх ставлення до християн, а також визначалися світськими міркуваннями здобичі та економічної або політичної вигоди тощо. Внаслідок вказаних причин українсько-турецькі та українськотатарські відносини цього часу були складним явищем, яке потребує додаткового досиідження.

Мета досмідження - здійснити спробу окреслити структуру проблеми українсько-татарських та українсько-турецьких взаємин та уявцень щодо них в останній третині XVII - на початку XVIII ст., виявити їх особливості.

Сучасна історіографія. Серед сучасних українських дослідників слід вказати на доробок у питанні українсько-татарських відносин ворожого характеру, що впливали на життя суспільства, О. Галенка. Дослідник, зокрема, здійснив грунтовний аналіз проблеми татарських набігів та присвяченої цій проблемі історіографії [1]. Переважно міждержавні українсько-турецькі та українсько-татарські стосунки досліджує у своїх працях Т. Чухліб [2].

Джеремьною базою дия проведення досиідження стали пам'ятки різного походження, як офіційного, так i наративного характеру. 3 офіційних джерел необхідно відзначити інформативність для теми дослідження документів (або їх описів), головним чином офіційного мистування, з Батуринського архіву, Конституції Пикипа Орлика 1710 р., угоди з Кримським ханством Петрика Іваненка 1692 р. та ін. 3 наративних джерел, деякі з яких можуть бути віднесені й до офіційних, необхідно згадати "Діаріуш" Івана Биховця, козацько-старшинські Григорія Грабянки

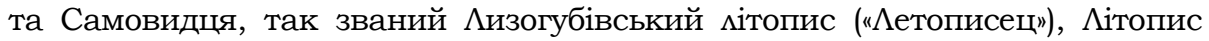
Мгарського монастиря, поезії $\Lambda$. Барановича, О. Бучинського-Яскольда та iн. [3-17]. 
Гносеологічні проблеми дослідження полягають у тому, що термінологія джерел не завжди однозначна. Зокрема, стосовно представників Кримського ханства та підпорядкованих йому ногайських орд зустрічаються терміни Крим, татари, орда (орди), іноді очевидно поняття орди та Кримське ханство (панство) змішуються, не завжди зрозуміло, про яких татар йдеться, ногайських чи власне кримських. Також проблемою $є$ видікення інформації щодо козаків або українців загалом, коли мова йде про міжнародні відносини, війни, до яких залучені "старі" держави, особливо коли вони є союзниками України. Часто в текстах при цьому фактичне козацько-турецьке чи козацько-російське військо описується як турецьке або московське. Для прикладу можна згадати один з фрагментів "Аітопису Самовидця", коли йдеться про взяття м. Канева у 1678 р. Автор згадує діяльність турецьких та татарських військ, але водночас говорить, що вони, в тому числі Яненко (Яненко-Хмельницький?), "Канев достали и вирубили мюдей". Таким чином, турецько-татарські війська включали фактично і українців протурецької орієнтації в періоди їх спільної діяльності. У "Аітописі Самовидця" зустрічається й більш чітке розділення автором турецького татарського військ та союзних їм козаків (П. Дорошенка) $[8$, с. 119,131$]$.

Ускладнює аналіз власне українсько-татарсько-турецьких стосунків і сприйняття у частині сучасних джерел козацько-російського війська у 1687 р., 1695 р., 1696, 1697 р. як "рать московську", "рать царя московського", "військо підступних москвитян" під проводом "боярина Акарича 3 роду Голіциних" (який брав участь у Кримському поході разом з козаками) [18, 563-564].

Весь комплекс українсько-турецьких та українсько-татарських взаємин та ідей навколо них можна поділити на дві головні групи, які в умовах прикордоння часто втрачали свою чистоту: ворожі (протистояння, боротьба) та союзні або мирні.

Боротьба з турками та татарами як запорука козацької смави. Одним з основних (але не єдиним) дискурсів останньої третини XVII початку XVIII ст. був той, який мав антитатарську та антиосманську спрямованість. До певної міри це була данина традиції, що визначала козацьку корпоративну, а також загальнонародну ідентичність, сформовану в добу жорсткого протистояння (як переважаючої форми відносин) до першої половини XVII ст. або до Богдана Хмельницького й актуалізовану новою міжнародною ситуацією. У цей час характеристика українського народу або козацтва часто здійснюється у контексті його ролі в боротьбі проти Османської імперії та ії васала Кримського ханства. Хоча імперія мала й інших васалів, таких, як Молдавське господарство, однак цей факт особливо не впливав, наскільки нам відомо, на існуючий дискурс.

Світсъкі аргументи на користь боротьби. Ворожий характер відносин у цей період грунтувався на міркуваннях як релігійного, так і світського характеру. Світський дискурс характеризувався ідеями необхідності повної перемоги над татарами, на чому наголошує, зокрема, О. Бучинський-Яскольд у своєму вірші "Охочекомонна стежка за трудящим воїном в році 1678-м" [17]. Поширювалася ідея традиційності перемог 
козацтва над турками, залежності козацької слави від характеру відносин 3 ними. Доблесть не тільки козаків, але й цілого народу (як "козацького"), визначається збереженням козацько-турецького протистояння. Це ми бачимо у творах авторів 3 яскраво вираженим антитурецьким та антитатарським спрямуванням. Так, $\Lambda$. Баранович у вірші "Світ на всі боки палає широко" писав: "О самопале, Ти нам немало докажеш всім слави, Татарам диким Зцамаєш шики - не викажуть справи!", "Русине славний, народ твій давній, Міг і турка бити, є що хвалити!" [11, с. 84]. Згодом подібні думки зустрічаємо й у козацького мітописця Г. Грабянки [7, с. 10].

Однією зі складових козацької слави було визволення від турків козацьких (українських) братів-невільників. $\Lambda$. Баранович бідкається в одному з віршів ("Щоби козацький човен на турків плинув знову"), що "славна Русь" змінилася, забулись мюбі браття, що стогнуть у турецькій невомі, бо брат брата "мегко тратить", а жінкам залишається чекати мирних договорів [12]. У зв'язку 3 цим варті особливої уваги повідомлення Г. Грабянки стосовно змішаних "малоросійсько"-запорозьких ватаг козаків, які після Вічного миру 1686 р. добровільно відправилися на прикордоння, в степи й здійснювали там стеження та напади на татар для звільнення бранців [7, с. 129].

У поезіях цього часу прославлялися герої, пов'язані з протистоянням проти Туреччини (турок) чи Кримського ханства (татар), формувався відповідний пантеон. У "Промові, проголошеній на смерть героя Підкови" зазначалося: "Так, це отой Підкова на тавриканських, на турецьких, на польських полях вікопомно impressit vestigia (залишив слід ноги), через якого, ніби Поліфемовий звук і відголос, не раз Оттоманська Порта мусіла хитатися і впадати..." [19, с. 373]. 3 іншого боку, козацько-татарське протистояння породжувало героїзацію опонентів, наприклад, з татарського боку. У цьому відношенні представцяють інтерес вірші смоленського шляхтича Н. Поплонського, який відзначає, що козаки не проти були б мати над собою такого пана як "салтан" (Перекопський бей) Шагин-Гірей ("Зная храбрость велику шагирей салтана, казаки себе иметь ради тебя пана"), який, в свою чергу, уславлюється як видатний військовий=державний діяч в контексті історії Кримського ханства. Автор висловлює думку, що добре, що раніше не було у татар таких правителів, і козаки над ними могли отримувати перемоги: “Шангирей салтан в Перекопі живет, А в поле всегда с ордою как шъет. Не дай Бгъ давней ... сюди того пана, Когда орда еже дней бувала щипана От руських голцов..." [20, с. 533-535].

Реєстри козацьких перемог над турками та татарами містяться у

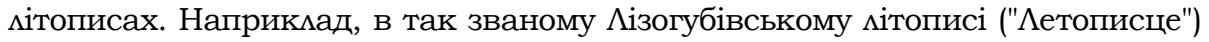
XVIII ст. до Б. Хмельницького тональність повідомлень виключно позитивна, вкцадається у підтвердження ідеологеми "козацької слави" [9, с. 3-5]. Коли вже мова йде стосовно Б.Хмемьницького, завдання мітописця у справі висвітлення козацько-турецьких та козацько-татарських відносин очевидно ускладнюється необхідністю опису союзницьких відносин та подій, коли татари відходили від союзу з козаками (наприклад, під час битви під Берестечком) [9, с. 8-11]. 
Протистояння прибічників різних вір. Релігія була важливим аргументом для виправдання та обгрунтування боротьби як в християнському (православному в даному випадку), так і мусульманському дискурсі. Так, у кримському мітописі другої половини XVIII ст. при описі подій 1687 р. наголошувалося на релігійному протистоянні ("правовірних мусульман" та "невірних") [21, с. 552-553]. Подібний підхід спостерігається і в джерелах українського (християнського) походження. Так, у мисті П. Дорошенка до запорожців (а саме Івана Сірка) 1676 р. він відкидає звинувачення I. Самойловича щодо себе, що нібито він, П. Дорошенко, надсилає білгородську та орди на Аівобережжя, використовуючи у спілкуванні з відомим своїми поглядами кошовим вираз "вороги святого хреста татари" [22, с. 133]. У "Списанні короткому про спалення трапези і про створення іiі знову, так оповідається" (16 мипня 1687 р.), автор згадує благодіяння I. Мазепи стосовно Мгарського монастиря та його участь у заснуванні мурованої трапезної у 1695 р. (під час Азово-Дніпровських походів), коли гетьман одержав перемоги над фортецями "ворогів святого хреста безбожних і христоненависних агарян" [10, с. 562]. $\Lambda$. Баранович у вірші "На 1680 рік" проголошував, що "...як на Київ турок руку здійме, Тоді Бог з могил мертвих проти них підійме... Християнам миш єдність на осман потрібна..."[13]. Про релігійне протистояння йдеться й у вірші "Турка зіб’ємо при Христовім знаку, вийди, поляку, русаку і козаку, при власнім сагайдаку" [15].

Ствердження позитивної ролі козацтва для "Росії" (мається на увазі Україна) та Польщі в працях козацьких мітописців (Г. Грабянки) здійснювалося за допомогою вказівки на його боротьбу проти мусульман та визволення християнських бранців [7, с. 10].

Релігійний дискурс простежується у характеристиці героїв боротьби з татарами. Якщо діямьність згаданого Івана Підкови описана в контексті світського дискурсу, то перелік заслуг Івана Сірка наводиться у зв'язку $з$ концептом боротьби християн і мусульман. Так, в "Короткому описі Сіркових діянь" від 1681 р. йому приписується вислів, що Бог "за хрест святий i бранця битися мені в житті призначив". Тут же він характеризується як християнський рицар [23, с. 177-178].

Ситуативні чи перспективні?: союзницькі та мирні відносини українців, турок та татар. Існування союзницьких відносин між козацтвом та Кримським ханством та Османською імперією свідчить про те, що релігійні мотиви у другій половині XVII ст. (як і в першій, коли згадаємо про козацький договір з татарами 1624 р.) були не єдиними в процесі формування політичних орієнтацій та союзів козацьких мідерів, тоді як у відносинах з Річчю Посполитою вони відігравали одну з ключових ролей.

Союз виступає і як засіб досягнення довгоочікуваного миру. Зокрема, $\Lambda$. Баранович у вірші "Світ стрясають грози на мюдскії сльози" автор закликає: "Хай Україна Буде єдина, татарин хай згине, Нехай на згоду Візьме угоду, хай мюбить русина!" [14, с. 82].

У джерелах відображена ще одна цікава політична мінія взаємин у контексті союзницьких відносин. Зокрема, можна простежити, що 
розглядалася українськими авторами можливість союзу християн з "ордою" (Кримським ханством) проти Османської імперії. Це було питання, у вирішенні якого зовсім не могли грати роль релігійні міркування, тому що йшлося про союз християн та мусульман, направлений проти мусульман. Тому на перший план виступають суто помітичні аргументи, ідея політичного "ярма", «іга", (популярна, зокрема, у контексті характеристики складних і неприйнятних для частини української еліти українськоросійських взаємин за гетьмана I. Виговського, згодом при I. Мазепі). Зокрема, $\Lambda$. Баранович (1680) вказує на ніби бажання татар звільнитися від "ярма" османів: "И Орда, що ії турки научивсь ярмити, Як золотом купити, стане турка бити, Вона також на волі хоче собі матись, Набридло перед турком завше умягатись" [15].

На окрему увагу заслуговує аргументація козацьких мідерів на користь союзу з Кримським ханством. В її основі часто межали ідеї щодо заслуг татар по відношенню до України та історичної традиції, започаткованої Б. Хмельницьким. Так, П. Іваненко вказує на роль татар у встановленні кордонів з Річчю Посполитою за Б. Хмельницького, які: "Хмельницький завоював із ордами від поляків"; тобто на традицію взаємин, розпочату Б. Хмельницьким [5, с. 334]. На необхідність оновлення давнього "братерства" $з$ "Панством Кримским" та "приязни суседской" посилається й Конституція Пилипа Орлика 1710 р. (пункт Г (III)) [4, с. 159]. Йосип Кириленко, кошовий Запорозької Січі в 1710 році, написав миста (2 червня 1710 р.) до гетьмана I. Скоропадського, в якому обгрунтовував звернення запорожців до шведського короля за допомогою проти московського "іга" не позицією кошового Я. Гордієнка, а, зокрема, традицією з часів Б. Хмельницького, який для визволення України тоді від "мядського ярма" мав союзником Кримське ханство та звертався до шведського короля [24].

Одним 3 важелів, який сприяв зближенню козацтва 3 Кримським ханством, було намагання зруйнувати небажані міжнародні союзи. Так, П. Іваненко у своїй відозві до запорожців вказував на можливість поділу України між ордою та Москвою у випадку зближення їх [25, с. 356-357].

3 погляду аргументації щодо встановлення мирних (союзних) взаємин 3 татарами представляє особливий інтерес "Чолобитна генеральної старшини супроти гетьмана Івана Самойловича від 7 мипня 1687 р." (донос проти гетьмана). Наведена в ній аргументація бума спрямована довести небажання I. Самойловича брати участь у війні з Кримським ханством. Гетьман, згідно чолобитній, був проти розірвання Московською державою мирної угоди з Османською імперією для укладання Вічного миру 3 Польщею (1686). Йому приписувалися міркування, що цей мир став запорукою зростання небезпеки з боку Кримського ханства та Туреччини. Гетьман був переконаний у шкідливості цієї війни дмя "нас" (козаків, України), своїм послам до татар наказував "усіма симами дбати про утвердження потуги своєї і дружби з Кримською державою" [26, с. 287289]. Отже, головним аргументом миру з Кримським ханством для I. Самойловича, згідно "Чолобитної...", виступав аргумент безпеки та "відсутності шкоди" дмя України. 
Важливу роль у забезпеченні миру відігравали окремі персоналії. Н. Поплонський, описуючи діяльність перекопського бея Шагін-Гірея, відзначає, що для Русі та татар в цей час властиві головним чином мирні відносини, а ворожі мають короткочасний характер, направлений на здобичництво, у тому числі на взяття мюдського ясиру [20, с. 535].

Сама ідея миру використовувалася у якості аргументу до укладення політичного союзу, наприклад, П. Іваненка 3 Кримським ханством, у преамбулі угоди було сказано, що здійснимося "давнє бажання "малоросійських жителів" про мир і вічне братство" [5]. До сфери мирних стосунків можна віднести переговорні процеси стосовно звільнення бранців з Кримського ханства та різноманітних суперечок, пов'язаних 3 порушенням права. Звернення до цього питання дозволить до деякої міри торкнутися проблеми соціально-економічної асиміляції звільнених самими татарами в Кримському ханстві українців, їх ролі у фінансових прибутках цієї держави. Багато відповідних відомостей містить діаріуш Івана Биховця. Зокрема, ханський візир надав право йому судити християн, звинувачених у змочині, як судді. Ці християни були представлені, зокрема, запорожцями, які були продані у невільництво в Крим. Хоча I. Биховець доклав багато зусиль, щоб переконати татар у невинуватості українських невільників і вони були звільнені, однак їм не було дозволено уїжджати "на Русь", вони мали залишатися і сплачувати податки, згідно місцевим законам [6, с. 587-588].

Коли союз з татарами та турками під питанням: козацька опозиція збциженню. Відсутність єдності в політичних орієнтаціях українського суспільства та козацтва, зокрема, що була зумовлена специфікою історичної ситуації та традиційної ідентичності, виявлялася й у питанні ставлення до татар та турок. Про це йдеться, наприклад, в "Думі" I. Мазепи, наведеної у доносі В. Кочубея на гетьмана. І. Мазепа висловлює свій жаль щодо долі України, вказуючи, що “Єден живеть із погани, Кличеть: "Сюда, отамани! Ідем матки рятовати, Не даймо їй погибати!". «Різно тебе розшарпали, Гди аж по Дніпр туркам дали» [27, с. 439].

У вересні 1689 р. І. Мазепа звернувся з низкою питань до Московської держави, на які отримав резолюції царя. Серед них було й питання стосовно того, що "..Запорожцы к Великим Государем к Их Царскому Величеству не устояли в своем повиновении і помирились с общим неприятелем креста святого крымским ханом..." [28, с. 255]. Тому I. Мазепа цікавився, як ставиться вмада до можливої відмови від цього союзу, чи відновиться попередні стосунки, включно з економічними. При цьому союз запорожців з татарами розглядався гетьманом тоді як тимчасовий відступ $\mathrm{i}$ підтримувалася ідея їх "повернення" [29, с. 255-256].

Непрямим свідченням різного ставлення запорожців до союзу 3 татарами антиросійського спрямування є інформація, вміщена в "Доносі козака Івана Явборського про зраду кошового отамана", в якому автор вказує на те, що кошовий отаман постійно ставив перед козаками на раді питання щодо спільного виступу запорожців з татарами (ордою) (в тому числі у присутності на раді посланців від татар), в той же час остаточний вибір запорозького війська - антиросійська чи антимазепинська позиція, - 
була поставлена в залежність від позиції кримського хана. У мисті посланці до хана від запорожців запитували його, "куды он с ордою ітти намерен, к Царскому ми Величеству, іли к Мазепе, ибо они с ними обще, куды они пойдут, ітти намерились" [29, с. 410-411].

У відозві до запорожців від 1693 р. 3 двома "цидумами" П. Іваненко натякає на несприйняття 3 боку частини запорожців (очевидно, прибічників промосковської орієнтаціі) триматися союзу 3 Кримом, говорячи про бажання союзу з боку самого Криму, на готовність кримської сторони забути про збитки з боку козаків. Водночас достатньо показово, що той же П. Іваненко, зустрівшись 3 порушенням 3 боку запорожців укладеної ним угоди з Кримським ханством (запорожці здійснили напади на татар), у "цидулі першій" до них відзначає, що серед небезпек можливого зближення Московії та Криму є небезпека поділу України, що означає і небезпеку для України від орди: "Москва, а й, помирившись 3 Кримом (як нині про те ревно дбає), вас із Січі вижене, вольності ваші військові відбере, України нашої частину віддасть орді в неволю, а решту візьме у свою неволю вічну". Показовою $є$ і приказка, що ії як аргумент використовує П. Іваненко: "Самі, ваша милосте, добрі молодці, військо Запорозьке, знаєте ту істинно правдиву казку, що за кого стоїть кримський хан, той буде й пан". Дıя переконання запорожців у необхідності антиросійського союзу з Кримським ханством П. Іваненко використовує $\mathrm{i}$ той аргумент, що в можливому між собою союзі Москва і Крим замкнуть дмя запорожців гирло Дніпра [25, с. 356-357].

Взаємна "кривда", взаємні "страхи". Представляє інтерес зіткнення різних аргументів навколо ідеї українсько-татарського союзу, яка породжувала проблему практичного його втілення, або забезпечення мирного співіснування. Поставали питання: як пом'якшити для української сторони (суспімьства) значення фактів жорстокості, "кривд" з боку татарськотурецького війська; яка буде сплата за союз; як бути, якщо взаємини мають негативні наслідки дмя церкви, як ставитися до питання шкоди татарам від козаків тощо [8, с. 119 тощо].

Одним 3 джерел "традиційних" страхів українців було захоплення ясиру татарами, татарські набіги. Так, у вірші $\Lambda$. Барановича "Татарин плюндрує, як у себе, кочує" автор говорить: "Нехай зірветься татарська тятива, Що з турком разом на кров нашу хтива...Хай бімьше гостра нас шабля не голить, Вже болю досить, нехай не неволить!" [16].

Розмогий перелік "кривд" турецьких містять козацько-старшинські мітописи, що написані (завершені) на початку XVIII ст. Зокрема, мітопис Самовидця описує трагічні для українських міст наслідки їх завоювання турками, шкоди від "орди" (наприклад, в 1678 р., в Переяславському повіті), шкоди від татар (також з Яненком) як цивільним, так і війську [8, c. $119,128,131-132,134,142$ та ін.].

Запобігти можливим збиткам у мюдях та майні, "кривді", що могли бути завдані з боку татар, а також і навпаки, намагався у своєму договорі $з$ Кримським ханством 1692 р. П. Іваненко (п. 4, 8), в тому числі враховуючи специфіку дій союзника й обіцяючи відкрити Муравський шлях, тобто направляючи практично татар на частину Слобожанщини, жителі двох 
полків якої мали переселитися "на чигиринський бік Дніпра" (Правобережну Україну - п. 5). Це зайвий раз свідчить про значну актуальність питання [5].

Існувала й, так би мовити, опосередкована кривда від татар. Очевидно, з діяльністю П. Іваненка та його прибічників пов'язана й пізніша згадка учасника азовського походу про "запорожника Пінчука", що зібрав супротивників "його імператорської величності" та чинив багато зма жителям низки українських міст, забираючи мюдей та продаючи їх у неволю до татар та турків [30, с. 594-595].

Причини для "страхів" були й у протимежної сторони. У відозві до запорожців від 1693 р. П. Іваненко вмовцяє запорожців триматися миру з татарами відповідно укладеного ним союзу, згадує про збитки з боку козаків "Криму" [25, с. 357]. Також представляє інтерес те, що ставлення до турецько-татарських бранців було різним в об'єднаній українськоросійській армії, зокрема, кримські та російські джерела вказують на особливу небезпеку для бранців з боку запорожців. Щоправда, у мітописі Давида Еліазара Кяхно про це прямо не йдеться. При характеристиці подій 1696 р., обставин взяття фортеці Нукрат-Керман, в мітописі вказується на дії проти мусульман російського війська (тобто автор джерела не розрізняв складових цього війська - власне російську та козацьку). Водночас є згадка про надмірну жорстокість щодо тих мусульманських бранців, які були відведені в "Буткали" (тобто Запоріжжя) [18, с. 563-564]. У російському джерелі мова йде про різні складові армії, що брала фортецю Кизикермен (1696): російських військових, козаків I. Мазепи (полкові), запорожці. Окремо згадується про те, що частина війська забезпечувала безпеку для "сиделцев" (жителів) Кизикермена від запорожців. Необхідно відзначити, що документ написаний від особи Шереметєва, але із вказівкою на участь у взятті Кизикермена I. Мазепи [31, с. 567].

Н. Поплонський, звертаючись до постаті перекопського бея ШагінГірея, вказує на те, що за цього правителя "татары от Руси (тобто України. - А.Н.) сущі безопасны", Русь (і запорозькі козаки - "буткали") не ризикує виступати проти нього, не мстить за взяття ясиру: "Тот вельможа богатыръ премудрі удачен I всем соседом порубежным страшен: Не допущает Руси с козаками Горы держати уж над татарами" [20, с. 533]. Більше того, він відносить до заслуг Шагін-Гірея те, що він "Обогатил орду бедну с Руси добычами" [32, с. 536].

У свою чергу, і козаки вдавалися до вчинення "кривд" татарському населенню, про що свідчить, зокрема, "Короткий опис Сіркових діянь від 1681 року", де йдеться про напади козаків на "села й паланки татарські", "сплюндрували осади очаківські всі в поганина", "нагайські коші зніс із місць цілковито". Така діяльність та жорсткість в контексті твору виглядає як "помста" за попередні кривди з боку татар християнам (спершу автор твору згадує, що "У час вієн, що Хмелем велись, од поганства немало Потерпав християнський народ, їх з майном забагато пропало") [23, с. 167, 171-172]. Про козацькі помсти за ясир згадує і Поплонський у своєму панегірикові Шагін-Гірею. Про козацькі походи на татар згадують 
козацько-старшинські мітописи, наприклад, про похід козаків під Очаків у 1694 р., коли "пригнано" до Батурина 300 чоловік ясиру [8, с. 154].

Свідчення про те, що нападу остерігалися не тільки християни від мусульман (українці від татар чи турок), але й навпаки, знаходимо у "Діаріуші Івана Биховця" (1704), який був посланцем Івана Мазепи до кримського хана Селім-Гірея. Одночасно з ним до Бахчисараю прибув відомий у свій час і згаданий вже Шагін-Гірей, салтан Перекопський, "котрий і тепер стоїть на Каланчаку, остерігаючись військ християнських на Крим приходу". В іншому місці Іван Биховець ще раз наголошує на тому, що є багато свідчень про, те що татари "боялися вельми приходу військового" [6, с. 584-585].

Особливим предметом побоювання в православному дискурсі була доля Києва, як метрополії православ'я, котрий міг потрапити під вмаду "турка". Про це свідчить, зокрема, "Синопсис Київський" (перше видання якого здійснено у 1674 р.) [33, с. 91-93].

Як предмет дмя особливого занепокоєння сприймався можливий союз одного з учасників внутрішньої системи українських взаємин (наприклад, Гетьманщини та Січі) з Кримом чи Османською імперією [34, с. 56]. Слід згадати й про політичні страхи Московської держави, причиною яких були стосунки козаків та турків й татар. Вони формувалися непевністю міжнародних відносин, коли існувала можливість ігнорування міждержавних домовленостей з боку козаків. Так, запорожці чинили спротив комісії Ф. О. Головіна з встановлення кордонів на півдні (1705 р.) [35, с. 138-139]. Відомості про перемир'я Російської держави 3 "салтаном турецьким" розсилалися до I. С. Мазепи та Січ з метою уникати всіляких "задорів" [36, c. 28].

Також вкрай негативно сприймалася російським урядом ситуація, коли козаки могли допомагати повертатися до Криму татарам та туркам, що прийняли християнство та осіли в Москві [37, с. 65].

Ставцення до татар та турок як важмивий емемент у характеристиці діяльності окремих гетьманів. Достатньо властивим для дискурсу українських православних авторів, в тому числі проросійського спрямування було звинувачення у схильності окремих політичних діячів до пошуку можливості встановлення відносин з турками та татарами. Це визначалося не тільки традицією, але й актуальною міжнародною ситуацією, політичною орієнтацією самих гетьманів.

У доносі-чолобитній козацької старшини проти гетьмана I. Самоймовича російським урядовцям 1687 р. (коми було здійснено Перший Кримський похід) вказувалося, що гетьман "не бажав того, щоб цим походом монарші сили мали перемогу над Кримом", що він вважав антиосманську та антитатарську позицію "москви" за помилкову, дав наказ гадяцькому полковнику Михайлу, згідно якому останній заявцяв, що: "Коли б нам самопали козацькі з'єднати із шаблями кримськими, сильні були б ми супроти всяких монархів" [26, с. 287, 289-290].

Єпископ Йосип Шумлянський вказує на негативний бік діяльності I. Самойловича, відповідно стійкому концепту щодо залежності козацької 
слави від перемог над турками та татарами: "туркам приязнь показав, козакові честь уйняв" (1686 р.) [38].

У донесенні В. Кочубея на I. Мазепу низка пунктів (з п. 18 та далі) присвячена підозрам про зв'язки гетьмана з "бусурманами". Йдеться про схвальне ставлення I. Мазепи до політики I. Виговського та I. Брюховецького як направценої на звільнення України 3-під влади Московської держави за допомогою Кримського ханства й Туреччини, контакти 3 представниками Туреччини та Кримського ханства (невдалі дмя задумів I. Мазепи) [27, с. 432-433]. Водночас поширювалися так звані "пашквимі" на I. Мазепу. В одному з них, який вразив змістом самого гетьмана, вказувалося, що ніби до свого гетьманства I. Мазепа "мюдей наших подільських, руських та волинських, на очах хапаючи, бусурманам продавав, церкви наші благочестиві, оклади та убори в них здираючи, туркам срібло продавав" [39, с. 329-330].

3 іншого боку, позитивні характеристики діяльності гетьманів (часто тих же самих осіб, але в інші періоди їх біографіï) теж знаходяться у прямій залежності від ставлення їх до татар (Кримського ханства) та турків (Османської імперії). Стефан Яворський, створюючи панегірик І. Мазепі у рік другого Кримського походу 1689 р., додає блиску його військовій славі за рахунок представлення його як противника Туреччини. Він сповнений очікування, що "Славний вождь Іван" виступить проти "Місяця" (що символізував Османську імперію) "і турецькій він гидрі насипле могили". Стефан Яворський закликає I. Мазепу: "До звитяжного Криму, гнізда, войовниче, Хай гербова, наш вожде, зоря тебе кличе" [40, с. 323-324].

Боротьба з "невіруючими татарами та іншими ворогами християнства" висувається в якості аргументу на користь заслуг I. Мазепи, достойних нагородженні його з боку цісаря Священної Римської імперії Іосифа I титулом князя Священної Римської імперії (особисто) [41, с. 226].

Отже, здійснений аналіз дозволив виділити наступні напрямки, вивчення яких дозволяє розкрити різні аспекти проблеми українськотурецьких та українсько-татарських взаємин в останній третині XVII - на початку XVIII ст. Це термінологічний напрямок, вивчення ворожих відносин у контексті світських та релігійних ідей, дослідження союзних та мирних (вкАючно з соціальною асиміляцією) відносин, вивчення головної мотивації, що використовувалася для обгрунтування необхідності союзів 3 Кримським ханством та Османською імперією в умовах, коли православ'я виступало осередком української ідентичності, анахіз використання українсько-татарських та українсько-турецьких відносин дмя формування пантеону героїв та надання позитивних чи негативних характеристик окремим діячам, в залежності від дискурсу та завдань авторів текстів. Також важливим $є$ напрямок дослідження психологічних аспектів відносин, впливу ментальності, емоцій, у контексті понять "кривди" та "страхів". Дослідження цих напрямків виявило складність українськотурецьких та українсько-татарських відносин, їх різновекторність, залежність від політичних та ідеологічних чинників, взаємну користь та шкоду, в залежності від конкретних історичних умов. 


\section{Джерема та мітература:}

1. Галенко О. Про татарські набіги на українські землі // Український історичний журнал. - 2003. - № 6. - С. 52-68.

2. Чухліб Т. Гетьмани і монархи. Українська держава в міжнародних відносинах 1648-1714 pp. / Наук. т-во ім. Шевченка в США, Ін-т історії України НАН України, НДІ козацтва. - Київ; Нью-Йорк: [б.в.], 2003. - 517 с.

3. Батуринский архив и другие документы по истории Украинского гетманства 1690-1709 гг. / рук. проекта и сост. Т. Г. Таирова-Яковлева; отв. ред. Т. А. Базарова. РАН. Санкт-Петербургский институт истории; СанктПетербургский государственный университет, Центр по изучению истории Украины. - СПб.: Дмитрий Буланин, 2014. - 480 с. (далі - БА).

4. Конституція Пимипа Орлика: оригінал та його історія / підгот. О. Б. Вовк // Архіви України. - 2010. - Вип. 3-4 (269). - С. 145-166.

5. Петро Іваненко. Статті вічного миру із ясновельможним його милістю ханом і 3 усією державою Кримською видільного Київського та Чернігівського князівства і всього Запорозького городового війська і народу малоросійського міта 1692, травня 26 дня / переклав суч. укр. мовою В. Шевчук // Тисяча років української суспільно-політичної думки: у 9 т. К.: Дніпро, 2001. - Т. 3, кн. 2: Остання чверть XVII - початок XVIII ст. / упоряд., резюме, приміт. В. Шевчука. - С. 332-336 (далі - ТРУСПД).

6. № 497. 1704. Діаріуш Івана Биховця // Доба гетьмана Івана Мазепи в документах / упоряд. С. Павленко. Київ: Видав. дім "Києво-Могилянська академія", 2007. - С. 584-591 (дамі - ДГІМвД).

7. Аітопис гадяцького полковника Григорія Грабянки / пер. із староукр. Р. Г. Іванченка. - Київ: Т-во "Знання" України, 1992. - 143 с.

8. Аітопис Самовидця / видання підготував Я. І. Дзира. - Київ: Наукова думка, 1971. -208 c.

9. Аетописец или описание краткое знатнейших действий и случаев, что в котором году деялося в Украине малороссийской обеих сторон Днепра и кто именно когда гетманом бым козацким // Сборник метописей, относящихся к истории Южной и Западной Руси. - Киев: Тип. Г.Т. Корчак-Новицкого, 1888. C. VII-XII, 1-69.

10. № 491. 1687-1709 pp. 3 мітопису Мгарського монастиря // ДГІМвД. С. 554563.

11. Мазар Баранович. Суспільно-політичні вірші 70-80 pp. XVII ст. Із книги "Апомлонова мютня". Київ, 1671 року. Світ на всі боки палає широко / пер. 3 пом. В. Шевчук // ТРУСПД. - С. 83-84.

12. Мазар Баранович. Суспільно-політичні вірші 70-80 рр. XVII ст. Із книги "Апомлонова мютня". Київ, 1671 року. Щоби козацький човен на турків плинув знову / пер. з пол. В. Шевчук // ТРУСПД. - С. 85.

13. Мазар Баранович. Із книги "Вінець Божої Матері". Чернігів, 1680 року. На 1680 рік / пер. з поц. // ТРУСПД. - С. 88-89.

14. Мазар Баранович. Суспільно-політичні вірші 70-80 рр. XVII ст. Із книги "Апомлонова мютня". Київ, 1671 року. Світ стрясають грози на мюдскії сльози / пер. $з$ пом. В. Шевчук // ТРУСПД. - С. 81-82.

15. Аазар Баранович. Суспільно-політичні вірші 70-80 pp. XVII ст. Із книги "Відмітка пяти ран Христових". Чернігів, 1680 року. Турка зіб'ємо при Христовім знаку, вийди, поляку, русину й козаку, при власнім сагайдаку / пер. $з$ пом. В. Шевчук // ТРУСПД. - С. 91. 
16. Мазар Баранович. Суспільно-політичні вірші 70-80 рр. XVII ст. Із книги "Апомлонова мютня". Київ, 1671 року. Татарин плюндрує, як у себе, кочує / пер. $з$ пол. В. Шевчук // ТРУСПД. - С. 83.

17. Олександр Бучинський-Яскольд. Чигирин. Охочекомонна стежка за трудящим воїном в році 1678-м / пер. 3 пом. В. І. Крекотня // Українська мітература XVII ст.: Синкретична писемність. Поезія. Драматургія. Белетристика / упоряд., приміт. В. І. Крекотня. - Київ: Наукова думка, 1987. - С. 311.

18. № 492. 1695-1696. - Давид Еліазар Аяхну. Уривок із книги-літопису "Девар-Сефатаїм" // ДГіМвД. - С. 563-564.

19. Із анонімної риторики "Меркурій у придбаному царстві". Київ, 1693 року. Промова, проголошена на смерть героя Підкови / пер. $з$ пол. та мат. В. Шевчук // ТРУСПД. - С. 372-379.

20. № 483. 1691. Крим. Пісня про Перекоп Никифора Поплонського // ДГІМвД. - С. 533-535.

21. № 490. 1687. - Крим. 3 анонімного Аітопису Кримського ханства, написаного в 1756-1766 роках на підставі давніших рукописів) // ДГІМвД. C. $552-553$.

22. Мист гетьмана Петра Дорошенка до запорожців від 21 березня 1676 року / переклав з книж. укр. мови В. Шевчук // ТРУСПД. - С. 133-135.

23. Анонім. 3 рукописної віршованої хроніки другої половини XVII століття. Короткий опис Сіркових діянь від 1681 року / пер. В. Шевчук // ТРУСПД. - С. 167179.

24. Йосип Кириленко. Аист до гетьмана Івана Скоропадського від 2 червня 1710 року / пер. $з$ книж. укр. мови В. Шевчук // ТРУСПД. - С. 477-484.

25. Петро Іваненко (Петрик). Відозва до Запорозької Січі із двома доданими цидулами від початку 1693 року / пер. І. Сварник // ТРУСПД. - С. 355-358.

26. Чолобитна генеральної старшини супроти гетьмана Івана Самойловича від 7 мипня 1687 р. / пер. В. Шевчук // ТРУСПД. - С. 287-295.

27. Василь Кочубей. Донесення на Івана Мазепу по статтях від 1708 року / пер. В. Шевчук // ТРУСПД. С. 426-448. Ст. 33. Дума пана гетьмана Мазепи, в якій значне проти держави великого государя виявцяється супротивенство. - С. 438440.

28. № 292. 1689, вересня 20 - Москва. Статті гетьмана I. Мазепи, подані царям Іоану Олексійовичу та Петру Олексійовичу про різні справи, та рішення останніх на них // ДГІМвД. - С. 254-259.

29. № 411. 1709, цютого 5. Донос козака Івана Явборського про зраду кошового отамана // ДГІМвД. - С. 410-411.

30. № 499. Розповідь про військову службу Андрія Степановича Петровського // ДГІМвД. - С. 592-595.

31. № 495. 1696. Список з відписки до государів та великих князів всія Русі Іоана Олексійовича і Петра Олексійовича боярина Бориса Шереметєва про взяття та розорення міста Казикермена // ДГІМвД. - С. 565-568.

32. № 484. 1691, міто. Крим. Похвала Шангирею салтану Никифора Попионського // ДГІМвД. - С. 535-537.

33. Новікова $\Lambda$. Історичний текст як картина минулого і як відображення реалій своєї доби: на прикладі "Синопсису" // Історія України в книжкових пам'ятках XVII - XVIII ст.: 3 колекцій Наукової бібліотеки ОНУ імені I. І. Мечникова. Одеса, 2011. - С. 80-97.

34. № 86. 1703 г., июня 12. Грамота Петра I И. С. Мазепе о замыслах запорожцев // БА. - С. 56-57. 
35. № 245. 1705 г., июля 5. Выписка о содержании письма Е. И. Украинцева И. С. Мазепе // БА. - С. 138-139.

36. № 5. 1699 г., мая 5. Выписка о содержании письма Н. М. Зотова И. С. Мазепе // БА. - С. 28.

37. № 110. 1703 г., августа 28. Грамота Петра I И. С. Мазепе о наказании трех запорожцев, которые тайно переправляли татар из Москвы в Крым // БА. - С. 6566.

38. Йосип Шумлянський. Дума з 1686 року / пер. $з$ книж. укр. мови В. Шевчук // ТРУСПД. - С. 271-274.

39. Іван Мазепа. Аист до російських царів Івана та Петра Олексійовичів, посланий із полковим мубенським писарем Аеонтієм Верховським 27 червня 1691 року. / пер. з рос. В. Шевчук // ТРУСПД. - С. 338-331; Пашквіль чи виказ. - С. 329-331.

40. Стефан Яворський. Із книжки "Ауна голосу в пустелі". Київ, 1689 року. "Куди, Місяцю, роги ти сунеш, скажений!" / пер. В. Шевчук // ТРУСПД. - С. 323-324.

41. № 266. 1707. Аист гетьмана I. Мазепи до цісаря Йосифа I // ДГІМвД. - С. 226227.

\section{References:}

1. Galenko O. Pro tatarski nabigy na ukrainski zemli [About Tatar Raids on Ukrainian Land]: Ukrainskyi istorychnyi zhurnal. 2003. № 6. S. 52-68. [in Ukrainian].

2. Chukhlib T. Hetmany $i$ monarkhy. Ukrainska derzhava $v$ mizhnarodnykh vidnosynakh 1648-1714 r. [Hetman and Monarchs. Ukrainian State in International Relations, 1648-1714]. Kyiv; New York, 2003. 517 s. [in Ukrainian].

3. Baturinskii arkhiv i drugie dokumenty po istorii Ukrainskogo getmanstva 1690-1709 r. [Baturin Archive and other Documents on the History of Ukrainian Hetmanship, 1690-1709] / ruk. proekta i sost. T. G. Tairova-Yakovleva. SPb.: Dmitrii Bulanin, 2014. 480 s. (in the following text - BA). [in Russian].

4. Konstytutsiia Pylypa Orlyka: oryginal ta yogo istoriia [Pylyp Orlyk Constitution: Original and its History] / pidgot. O. B. Vovk: Arkhivy Ukrainy. 2010. Vyp. 3-4 (269). S. 145-166. [in Ukrainian].

5. Petro Ivanenko. Statti vichnogo myru iz yasnovelmozhnym yogo mylistiu khanom i $z$ usiieiu derzhavoiu Krymskoiu vydilnogo Kyjivskogo ta Chernigivskogo kniazivstva i vsiogo Zaporozkogo gorodovogo vijska i narodu malorosijskogo lita 1692, travnia 26 dnia [Articles of Eternal Peace, with Noble by his Mercy Khan and all Crimean State of Appanage Kiev and Chernigov Principality and the whole Zaporozhian City (Cossacks) Army and the Little Russia People Summer 1692, May 26]: Tysiacha rokiv ukrainskoii suspilno-politychnoii dumky. Kyiv: Dnipro, 2001. T. 3, kn. 2. S. 332-336. (in the following text - TRUSPD). [in Ukrainian].

6. № 497. 1704. Diariush Ivana Bykhovtsa [Diary of Ivan Bykhovets]: Doba hetmana Ivana Mazepy u dokumentakh. Kyiv: VD "Kyievo-Mogylianska akademiia", 2007. S. 584-591. (in the following text - DGMvD). [in Ukrainian].

7. Litopys gadiatskogo polkounyka Grygoriia Grabyanky [The Chronicle of Gadyach Colonel Gregory Grabyanka]. Kyiv: T-vo "Znannia" Ukrainy, 1992. 143 s. [in Ukrainian].

8. Litopys Samouydtsia [The Records of Eye-Witness]. Kyiv: Naukova dumka, 1971. 208 s. [in Ukrainian].

9. Letopisets ili opisaniie kratkoie znatniejshykh dejstvii i sluchayev, chto v kotorom godu deyalosia v Ukrainie malorossijskoi obieikh storon Dniepra i kto imenno kogda getmanom byl koztskim [Chronicle or brief description of the notable action and cases, what in which year took place in Little Russian Ukraine 
of both sides of the Dnipro and who exactly when the hetman of Cossack was]: Sbornik lietopisiej otnosiaschikhsia $k$ istorii Yuzhnoi i Zapadnoi Rusi. Kiev: Tip. G. T. Korchak-Novitskogo, 1888. S. VII-XII, 1-69. [in Russian].

10. № 491. 1687-1709 pp. Z litopysu Mgarskogo monastyria [From the Chronicle of Mgar cloister] // DGIMvD. S. 554-563. [in Ukrainian].

11. Lazar Baranovych. Suspilno-politychni virshi 70-80 r. XVII st. Iz knygy "Apollonova liutnia". Kyiv, 1671 roku. Svit na vsi boky palaye shyroko [Sociopolitical poems of $70-80$ years of XVII century. From the book "Apollon's lute". Kyiv, 1671. The world on all sides is burning] // TRUSPD. S. 83-84. [in Ukrainian]. 12. Lazar Baranovych. Suspilno-politychni virshi 70-80 r. XVII st. Iz knygy "Apollonova liutnia". Kyiv, 1671 roku. Schoby kozatskyi choven na turkiv plynuv znovu [Socio-political poems of $70-80$ years of XVII century. From the book "Apollon's lute". Kyiv, 1671. To the Cossack boat towards Turks sail again]: TRUSPD. S. 85. [in Ukrainian].

13. Lazar Baranovych. Iz knygy "Vinets Bozhoii Materi" [From the book "The Crown of the Mother of God". Chernigiv, 1680 year. For 1680 year: TRUSPD. S. 8889. [in Ukrainian].

14. Lazar Baranovych. Suspilno-politychni virshi 70-80 r. XVII st. Iz knygy "Apollonova liutnia". Kyiv, 1671 roku. Svit striasayut grozy ta liudskiye sliozy [Socio-political poems of $70-80$ years of XVII century. From the book "Apollon's lute". Kyiv, 1671. The world is shaked by a storm and human tears]: TRUSPD. S. 81-82. [in Ukrainian].

15. Lazar Baranovych. Suspilno-politychni virshi 70-80 r. XVII st. Iz knygy "Vidmitka piaty ran Khrystovykh. Chernigiv, 1680 roku. Turka zib'yemo pry Khrystovim znaku, vyjdy, poliaku, rusynu i kozaku, pry vlasnim sagajdaku [Sociopolitical poems of $70-80$ years of XVII century. From the book "The Sign of the Five Wounds of Christ". Chernigiv, 1680. The Turk will be defetaed under Christ's sign, come out, a Pole, a Rusyn and a Cossack, with own Sagaidak"]: TRUSPD. S. 91. [in Ukrainian].

16. Lazar Baranovych. Suspilno-politychni virshi 70-80 r. XVII st. Iz knygy "Apollonova liutnia". Kyiv, 1671 roku. Tataryn pliundruye, yak u sebe, kochuye [Sociopolitical poems of $70-80$ years of XVII century. From the book "Apollon's lute". Kyiv, 1671. Tatar destroys, as in his land, leads a nomad's life]: TRUSPD. S. 83. [in Ukrainian].

17. Oleksandr Buchynskyi-Yaskold. Chygyryn. Okhochekomonna stezhka za trudiaschym voinom v rotsi 1678-m [Volunteer Path Followig the Diligent Warrior in 1678]: Ukrainska literatura XVII st. Kyiv: Naukova dumka,1987. S. 311. [in Ukrainian]. 18. № 492. 1695-1696. - David Eliezer Lyakhnu. Uryvok iz knygy-litopysu "Devar-Sefataim" [David Eliezer Lyakhnu. The fragment from the book-Chronicle "Devar-Sefataim": DGMvD. S. 563-564. [in Ukrainian].

19. Iz anonimnoyi rytoryky "Merkurij u prydbanomu tsarstvi". Kyiv, 1693 roku. Promova, progoloshena na smert geroya Pidkovy [From the Anonymous Rhetoric "Mercury in the Purchased Realm". Kyiv, 1693. Speech, Proclaimed to Death of the Hero Pidkova]: TRUSPD. [in Ukrainian].

20. № 483. 1691. - Krym. Pisnia pro Perekop Nykyphora Poplonskogo [Crimea. The Song about Perekop by Nykyphor Poplonsky: DGMvD. S. 533-535. [in Ukrainian].

21. № 490. 1687. - Krym. $Z$ anonimnogo litopysu Krymskogo khanstva, napysanogo v 1756-1766 rokakh na pidstavi davnishykh rukopysiv [Crimea. From an Anonymous Chronicle of the Crimean Khanate written in 1756-1766 years on the basis of older manuscripts]: $D G M v D$. S. 552-553. [in Ukrainian]. 
22. Lyst hetmana Petra Doroshenka do zaporozhtsiv vid 21 bereznia 1676 roku [The Letter of Hetman Petro Doroshenko to the Zaporozhian Cossacks of March 21, 1676]: TRUSPD. S. 133-135. [in Ukrainian].

23. Anonim. $Z$ rukopysnoyi virshovanoyi khroniky drugoyi polovyny XVII st. Korotkyi opys Sirkovykh diyan vid 1681 roku [Anonymous. From handwritten poetic chronicles of the second half of XVII century. Brief description Sirko's activities 1681 year]: TRUSPD. S. 167-179. [in Ukrainian].

24. Yosyp Kyrylenko. Lyst do hetmana Ivana Skoropadskogo vid 2 chervnia 1710 roku [The Letter to Ivan Skoropadsky on June 2, 1710]: TRUSPD. S. 477-484. [in Ukrainian].

25. Petryk Ivanenko. Vidozva do Zaporozkoyi Sichi iz dvoma dodanymy tsydulamy vid pochatku 1693 roku [Proclamation to the Zaporozhian Sich with two added notes from the beginning of 1693]: TRUSPD. S. 355-358. [in Ukrainian].

26. Cholobytna generalnoyi starshyny suproty hetmana Ivana Samojlovycha vid 7 lypnia 1687 r. [Choloytna of general officers against Hetman Ivan Samoilovych of July 7, 1687]: TRUSPD. S. 287-295. [in Ukrainian].

27. Vasyl Kochubej. Donesennia na Ivana Mazepu po stattyakh vid 1708 roku. 33. Duma pana $\mathrm{h}$ etmana Mazepy, v yakij znachne proty derzhavy velykogo gosudaria vuyavliayetsia suprotyvenstvo [Report against Ivan Mazepa in articles. 33. Duma of master Mazepa which is significant by opposition against the state of great sovereign]: TRUSPD. S. 426-448, 438-440. [in Ukrainian].

28. № 292. 1689, veresnia 20 - Moskva. Statti hetmana I. Mazepy, podani tsariam Ioannu Oleksiyovychu ta Petru Oleksiyovychu pro rizni spravy, ta rishennia ostannikh na nykh [Articles of the Hetman Ivan Mazepa, submitted to the Kings Ioann Oleksiyovych ta Petr Oleksiyovych about various cases, and their decisions]: DGIMvD. S. 254-259. [in Ukrainian].

29. № 411. 1709, lyutogo 5. Donos kozaka Ivana Yavborskogo pro zradu koshovogo otamana [Denunciation of Cossack Ivan Yavborsky about betrayal of Kosh Ruler]: $D G I M v D$. S. 410-411. [in Ukrainian].

30. № 499. Rozpovid pro vijskovu sluzhbu Andriya Stepanovycha Petrvskogo [The Story about military service of Andrei Stepanovich Petrovsky]: DGIMvD. S. 592-595. [in Ukrainian].

31. № 495. 1696. Spysok z vidpysky do gosudariv ta velykykh kniaziv vsiya Rusi Ioanna Oleksiyovycha i Petra Oleksiyovycha boyaryna Borysa Sheremeteva pro vziattia ta rozorennia mista Kazykermena [The Copy of note to the masters and great princes of all Russia Ioann Oleksiyovych and Petr Oleksiyovych from boyar Boris Sheremetev about the capture and destruction of Kazykermen]: DGIMvD. S. 565-568. [in Ukrainian].

32. № 484. 1691, lito. - Krym. Pkhvala Shangireyu saltanu Nykyphora Poplonskogo [Crimea. The praise of Shangirey saltan by Nykyphor Poplonsky]: DGIMvD. S. 535-537. [in Ukrainian].

33. Novikova L. Istorychnyi tekst yak kartyna mynulogo i yak vidobrazhennia realii svoyei doby: na prykladi "Synopsysu" [Historical text as a picture of the past and the reflection of the realities of its epoch: on the example of "Synopsis"]: Istoriya Ukrainy $v$ knyzhkovykh pam'yatkakh XVII - XVIII st.: z kolekcij Naukovoii biblioteky ONU im. I. I. Mechnykova. Odesa, 2011. S. 80-97. [in Ukrainian].

34. № 86. 1703 r., iyun 12. - Gramota Petra I I. S. Mazepie o zamyslakh zaporozhtsev [Diploma of Peter I I. S. Mazepa about intentions of Zaporozhian Cossacks]: BA. S. 56-57. [in Russian].

35. № 245. 1705 r., iyul 5 - Vypiska o soderzhanii pisma E. I. Ukrainintseva I. S. Mazepe [The notes about content of E. I. Ukrainintsev's letter I. S. Mazepa]: BA. S. 138-139. [in Russian]. 
36. № 5. 1699 r., maya 5 - Vypiska o soderzhanii pisma N. M. Zotova I. S. Mazepe [The notes about content of N. M. Zotov's letter I. S. Mazepa]: BA. S. 28. [in Russian].

37. № 110. 1703 r., avgusta 28. - Gramota Petra I I. S. Mazepe o nakazanii triokh zaporozhtsev, kotoryie tajno perepravliali tatar iz Moskvy v Krym [Diploma of Peter I I. S. Mazepa about punishment of three Zaporozhian Cossacks who in secret transported tatars rom Moskow to Crimea]: BA. S. 65-66. [in Russian].

38. Yosyp Shumlianskij. Duma z 1686 roku [Duma from 1686 year]: TRUSPD. S. 271-274. [in Ukrainian].

39. Ivan Mazepa. Lyst do rossijskykh tsariv Ivana ta Petra Oleksiyovychiv, poslanyj iz polkovym lubenskym pysarem Leontiem Verkhovsky 27 chervnia 1691 roku [The Letter to the Russian tsars Ioan and Petr Oleksiyovych, sent with the regimental Lubny clerk Leontij Verkhovsky on June 27, 1691: TRUSPD. S. 328-331, 329-331. [in Ukrainian].

40. Stefan Yavorskij. Iz knyzhky "Luna golosu v pusteli". Kyiv, 1689 roku. "Kudy, Misiatsiu, rogy ty sunesh, skazhenyj!" [From the book "Echo of Voice in the Desert". Kyiv, 1689. "Where, the Moon, the horns you poke, the furious!": TRUSPD. - S. 323324. [in Ukrainian].

41. № 266. 1707. - Lyst hetmana I. Mazepy do tsisaria Yosyfa I [The Letter from Hetman Ivan Mazepa to Emperor Josef I]: DGIMvD. S. 226-227. [in Ukrainian].

\author{
июдмила Новикова \\ ORCID: https://orcid.org/0000-0003-4764-7867 \\ Кандидат исторических наук, доцент \\ Одесского национального университета имени И. И. Мечникова \\ УА. Дворянская, 2, Одесса, 65082, Украина \\ lyudmilanovikova@hotmail.com
}

\title{
К вопросу об особенностях украинско-турецких и украинско- татарских отночений в последней трети XVII - начале XVIII cm.
}

В статье рассматривается проблема украинско-туреиких и украинскотатарских отношений в последней трети XVII - начале XVIII cm. Для этого периода було характерна перегруппировка политических интересов в ЦентральноВосточной Европе, когда система договоров, которая создавалась, и ее эволюиия порождали у украинских гетманов разные опасения относительно судъбы Украины, подталкивали их к поиску контактов с Крымским ханством и Османской империей. У этих контактов на государственном и особенно обшественном уровне существовала уже достаточно противоречивая традииия. Свою роль играл и идейный контекст, связанный феноменом идентичности (казаческой, украинской), которая часто вступала в противоречие с идеологическим оформлением реальной политики того времени. В то же время свое представление и традииию относительно украинской стороны имели, в свою очередь, представители крымского ханства и Османской империи, которые формировались в контексте их отношения $\kappa$ христианам, а также определялись светскими соображениями добычи и экономической выгоды. Вследствие указанных причин украинско-туреикие и украинскотатарские отношения этого времени были сложным явлением, которое, несмотря на существуюшую историографию (например, работы А. Галенко и Т. Чухлиба), требует дополнительного исследования. Кроме изучения фрактического материала и попытки реконструкиии украинско-туреиких и украинско-татарских отношений в избранный период, в статье была осуществлена и попытка определить возможную структуру проблемы.

Осуиествленный с привлечением офиииальных и нарративных источников анализ украинско-туреиких и украинско-татарских отношений в последней трети XVII - в начале XVII в. позволил выделить следуюшие направления, изучение которых позволяет раскрыть разные аспекты проблемы: терминологический; 
изучение враждебных отношений в контексте светских и религиозных идей, исследование союзных и мирных (включительно с соииальной ассимиляиией) отношений; изучение главной мотиваиии, которая использовалась для обоснования необходимости союзов с Крымским ханством и Османской империей в условиях, корда православие определяло украинскую идентичность; анализ использования украинско-туреиких и украинско-татарских отношений для формирования пантеона героев и обеспечения положительных или отрииательных характеристик отдельным деятелям, в зависимости от дискурса и задач авторов текстов. Также является важным направление, связанное с исследованием психологических аспектом отношений, влияния ментальности, эмоций, в контексте понятий "обида" и "страх". Исследование этих направлений выявило сложность самого понятия "украинско-туреикие и украинско-татарские отношения", их разновекторность, зависимость от политических и идеологических факторов, влияние на формирование обшественных дискурсов.

ключевые слова: украинско-туреикие отношения в последней трети XVII начале XVIII cm.; украинско-татарские отношения в последней трети XVII - начале XVIII cт.; Крымское ханство; украинский Гетманат и его общество; украинское казачество; история идей в Украине в раннемодерный период.

Отримано: 05.12.2019p. 